\title{
Melanin production and laccase mediated oxidative stress alleviation during fungal-fungal interaction among basidiomycete fungi
}

\author{
Samim Dullah', Dibya Jyoti Hazarika1,2, Gunajit Goswami², Tanushree Borgohain', Alokesh Ghosh', \\ Madhumita Barooah", Ashok Bhattacharyya ${ }^{3}$ and Robin Chandra Boro ${ }^{1 *}$ (D)
}

\begin{abstract}
Fungal-fungal interaction often leads to the change in metabolite profile of both the interacting fungus which may have potential implication in industry or agriculture. In the present study, we performed two sets of fungal-fungal interaction - Trametes coccinea (F3) with Leiotrametes lactinea (F9) and T. coccinea (F3) with T. versicolor (F1) to understand the changes in the metabolite profile during the interaction process and how this process impacts the hyphal/ mycelial morphology of the participating fungi. The metabolites produced during interaction of T. coccinea (F3) with L. lactinea (F9) and T. coccinea (F3) with T. versicolor (F1) was analysed through liquid chromatography coupled to mass spectroscopy (LC-MS). Most of the metabolites secreted or produced during interaction are associated with defensive response. Further, visualization with scanning electron microscopy revealed that interaction between the tested fungi led to the changes in the hyphal morphology. The bipartite fungal interaction resulted in the production of a dark brown colour pigment-melanin as confirmed by the LC-MS, FTIR and NMR analysis. Moreover, the fungal-fungal interaction also led to increase in the production of laccase, a group of multicopper oxidases involved in detoxification of toxic compounds. Further, increased activity of superoxide dismutase, an enzyme that catalyzes the dismutation of the superoxide anion to hydrogen peroxide was also recorded during fungal-fungal interaction. Quantitative real-time PCR revealed upregulation of ICCl (encoding a laccase enzyme) and few other stress related genes of $T$. versicolor during its hyphal interaction with T. coccinea, suggesting a direct correlation between laccase production and melanin production.
\end{abstract}

Keywords: Hyphal interactions, Laccase, Melanin, NMR spectroscopy, Superoxide dismutase, ROS, qRT-PCR

\section{Introduction}

Fungal-fungal interactions are highly dynamic phenomenon which occurs in nature, whereby the interacting fungi compete for available nutritional source and territory. These interactions lead to the induction of an array of bioactive products by stimulating the complex metabolic pathways (Bertrand et al. 2014). Co-culturing

*Correspondence: robinboro@gmail.com

1 Department of Agricultural Biotechnology, Assam Agricultural University, Jorhat, Assam 785013, India

Full list of author information is available at the end of the article fungal species results in the production of some novel metabolites as a response to antagonistic interaction (Chatterjee et al. 2016). Few studies have been carried out to unravel the morphological and enzymatic changes during fungal interaction. During interaction of two different fungal species, various metabolic pathways get induced in the zones of barrage formation. The induction of certain metabolic pathways are due to the production of toxins, growth inhibitors and their by-products (Rodriguez et al. 2011). Phelligridin $\mathrm{C}$, phelligridin $\mathrm{H}$, methyl inoscavin $\mathrm{A}$, inoscavin $\mathrm{C}$, methyl davallialactone and foscoparianol D are some original author(s) and the source, provide a link to the Creative Commons licence, and indicate if changes were made. The images or other third party material in this article are included in the article's Creative Commons licence, unless indicated otherwise in a credit line to the material. If material is not included in the article's Creative Commons licence and your intended use is not permitted by statutory regulation or exceeds the permitted use, you will need to obtain permission directly from the copyright holder. To view a copy of this licence, visit http://creativecommons.org/licenses/by/4.0/. 
compounds observed during the co-culture of Inonotus obliquus and Phellinus punctatus (Zheng et al. 2011). During interaction, alcohols, aldehydes, ketones, terpenes, aromatic compounds and reactive oxygen species (ROS) are produced as a result of antagonism (Evans et al. 2008), which leads to the up-regulation of many oxidative enzymes like laccase, manganese peroxidase, lignin peroxidase (Gregorio et al. 2006). For instance, dual culture of Trichoderma and Metarhizium leads to oxidative stress and production of sugar alcohols in the zone of interaction (Medina et al. 2020). Tamayo et al. (2016) reported that the increase in ROS activated enzymes like superoxide dismutases (SODs) which acted as first line of defense.

Interspecific interaction among wood rotting basidiomycetes is a natural phenomenon of the ecosystem dynamics. For example, Ganoderma applanatum, Gloeophyllum trabeum, Irpex lacteus, Pleurotus ostreatus, Trametes coccinea, and T. versicolor, are some of the common wood inhabiting basidiomycetes that occupy the same microhabitat (Song et al. 2012). The outcome of such interactions can be either replacement-where one fungus gains the territory of the other, or deadlock-where neither of the two interacting fungi gains the territory of one another. Interactions among these basidiomycete fungi in the environment may help in decomposing and cycling of nutrients like carbon and nitrogen, thus exhibiting beneficial effects to the environment. Besides environmental utility, the interactions also have numerous industrial application such as induction of industrially important enzymes like laccase, xylanase, cellulase; production of important novel bioactive compounds. Therefore, understanding the basic metabolism and molecular mechanism is essential for their industrial and biotechnological applications. In a previous study, we assigned different grades of interaction during in vitro dual culture of different basidiomycete and ascomycete fungi. Our study revealed that T. coccinea (F3), when interacted with $T$. versicolor ( $\mathrm{F} 1)$ and L. lactinea (F9), formed a deadlock type of interaction with significant increase in the production of hydrolytic enzymes (Dullah et al. 2021). In the present study, the metabolic responses of the confronting mycelia of these fungal species were assessed during in vitro interspecific interaction of T. coccinea with T. versicolor and T. coccinea with L. lactinea using liquid chromatography-mass spectrometry (LC-MS). The interactions of T. coccinea with T. versicolor and T. coccinea with L. lactinea were chosen based on their morphological studies as well as their promising laccase and superoxide dismutase activity observed during interaction. The study also focuses on analyzing an important natural product-melanin produced during the interaction.

\section{Materials and methods}

Strains and culture condition

Three previously isolated fungal isolates viz., Trametes versicolor F1 (MK370665), T. coccinea F3 (MK168589) and Leiotrametes lactinea F9 (MK168586) were obtained from the Microbial Biotechnology laboratory, Department of Agricultural Biotechnology, Assam Agricultural University, Jorhat for the interaction studies. These species were characterized previously based on their morphological characters and molecular information of the internal transcribed spacer (ITS) region (Dullah et al. 2021). The cultures were grown on potato dextrose agar (PDA) (Himedia, India) and incubated at $28^{\circ} \mathrm{C}$.

\section{Interaction study between the fungal isolates}

For mono-cultures, a $7 \mathrm{~mm}$ agar plug of the fungal culture was inoculated in petri dish containing potato dextrose agar (PDA). T. coccinea versus L. lactinea and $T$. coccinea versus T. versicolor were dual cultured by inoculating $7 \mathrm{~mm}$ agar plugs of each isolate onto the opposite sides of a PDA plate and incubated at $28^{\circ} \mathrm{C}$ for $15 \mathrm{~d}$.

\section{Visualization of interacting fungi under scanning electron microscope (SEM)}

The hyphae from both the interacting cultures i.e., $T$. coccinea versus $T$. versicolor and $T$. coccinea versus $L$. lactinea and the monocultures on the 9th, 12th and 15th day of incubation were taken and fixed in $2.5 \%$ glutaraldehyde (prepared in $0.1 \mathrm{M}$ phosphate buffer), following the protocol of Kathuria et al. (2014). Scanning electron microscopic analysis was done using FEI Quanta 250 SEM at an accelerating voltage of $10 \mathrm{kV}$ with a scanning electron detector for taking micrographs at different magnifications.

\section{Metabolite extraction for LC-MS}

The two fungal dual cultures ( $T$. coccinea with L. lactinea and $T$. coccinea with $T$. versicolor) at their 8th day of interaction were considered for metabolite extraction for LC-MS and HRMS (High-Resolution Mass Spectrometry) (Fig. 1). The single cultures of T. coccinea, T. versicolor and L. lactinea were taken as control. The excised mycelia were mixed in a solvent containing methanol: dichloromethane: ethyl acetate in the ratio of $1: 2: 3$. It was placed in a rotary shaker at $120 \mathrm{rpm}$ for $12 \mathrm{~h}$ and sonicated. The filtrate was dried in a rotary evaporator system (IKA ${ }^{\circledR}$, Staufen, Germany). The powdered extract of each interaction and monoculture obtained was redissolved in methanol. The extract was filtered through $0.22 \mu \mathrm{m}$ syringe filter. LC-MS was carried out using an Agilent 1260 Infinity HPLC (High-Performance Liquid Chromatography) system (Agilent Technologies, Santa Clara, CA, USA) equipped with an auto sampler. 

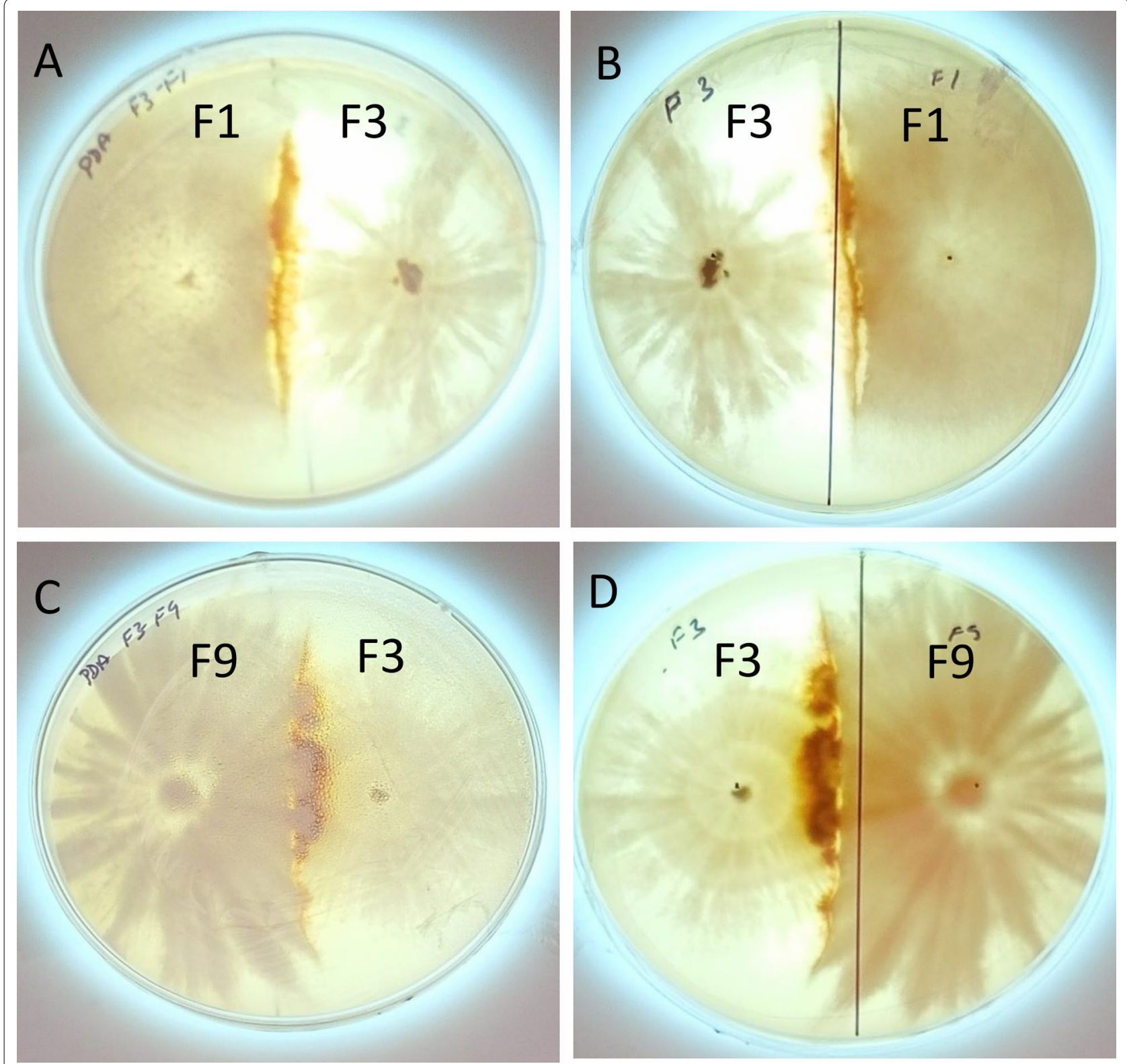

Fig. 1 Interspecific interactions of T. coccinea with T. versicolor and T. coccinea with L. lactinea. A, B Front and back view of the interaction between T. coccinea and T. versicolor. C, D. Front and back view of the interaction between T. coccinea and L. lactinea

An injection volume of $20 \mu \mathrm{l}$ was loaded into the system and the separation of individual compounds was carried out through a C18 column [250 length $\times 4.5 \mathrm{~mm}$ internal diameter (ID), pore size: $5 \mu \mathrm{m}$ ] with a gradient elution condition consisting of mobile phase: acetonitrile (solvent $\mathrm{A}$ ) and $0.01 \%$ formic acid in water (solvent $\mathrm{B}$ ). The gradient profile was as follows: $95 \%$ solvent $B$ at $0-5 \mathrm{~min}$, $70 \%$ solvent B at $6-11 \mathrm{~min}, 40 \%$ solvent $B$ at $12-19 \mathrm{~min}$, $20 \%$ solvent $B$ at $20-25 \mathrm{~min}, 95 \%$ solvent $B$ at 26 min and continued till $30 \mathrm{~min}$. The flow rate was $1.5 \mathrm{ml} / \mathrm{min}$. The separated compounds were ionized using the electrospray ionization (ESI) in the positive mode and detected using the MS detector coupled to the HPLC system. The scan range was from 80 to $1000 \mathrm{~m} / \mathrm{z}$. The HRMS analysis was performed in a Xevo G2-XS QT of HRMS system (Waters Corp, Milford, MA, USA) by injecting $10 \mu \mathrm{l}$ of the extracts, and the positively ionized adduct ions were detected. The molecular weights were confirmed by comparing with the exact mass of compounds obtained from PubChem (NCBI, Maryland, USA). 


\section{Data extraction and compound identification}

The peaks from ESI positive chromatogram containing the $\mathrm{m} / \mathrm{z}$ ratio in one axis and the relative abundance (\%) in the other axis for different retention time were analyzed for the presence of different compounds based on the adduct ions formed. The molecular mass for each retention time was predicted by identifying the different adducts. The molecular mass thus obtained were compared with the molecular weight of the reference compounds from different sources including Yeast Metabolome Database, PubChem, NIST molecular database. Some references were specific for a particular species whereas some were based on common metabolites secreted by fungal species.

\section{Production and extraction of brown pigment}

For brown pigment production during interaction, $7 \mathrm{~mm}$ mycelial plug from $T$. coccinea versus $L$. lactinea and $T$. coccinea versus $T$. versicolor were inoculated in $100 \mathrm{~mL}$ of Sabouraud broth (SB) (Himedia, India). Monocultures of $T$. coccinea, L. lactinea and $T$. versicolor were also inoculated and incubated at $28{ }^{\circ} \mathrm{C}$ for $21 \mathrm{~d}$. A flask containing media without inoculum was taken as control. When the colour of the broth changed, the mycelial biomass was removed and $1 \mathrm{M} \mathrm{NaOH}$ was added to the filtrate making the solution alkaline with $\mathrm{pH} 10$ and autoclaved at $120{ }^{\circ} \mathrm{C}$. The solution was centrifuged at $8000 \mathrm{rpm}$ for $20 \mathrm{~min}$. The filtrate was acidified to $\mathrm{pH} 2$ by adding $\mathrm{HCl}$ and centrifuged at $8000 \mathrm{rpm}$ for $15 \mathrm{~min}$. The precipitate was washed with organic solvents and HPLC grade water to remove any acid traces and dried at room temperature. The dried pigment was collected and weighed (Arun et al. 2015; Sun et al. 2017).

\section{Characterization of brown pigment}

The dried pigment was characterized for its solubility in water, $1 \mathrm{M} \mathrm{KOH}, 1 \mathrm{M} \mathrm{NaOH}$ and organic solvents like ethanol, hexane, and acetone. Reactivity of the pigment with hydrogen peroxide was tested by reacting $50 \mathrm{mg}$ melanin with $30 \% \mathrm{H}_{2} \mathrm{O}_{2}$, followed by precipitation with $1 \mathrm{~mol} / \mathrm{L} \mathrm{HCl}$.

\section{HPLC analysis}

The HPLC analysis was done by following the protocol of Sun et al. (2016). The extracted melanin pigment (after purification using TLC) and the commercially available melanin (Sigma, USA) were dissolved in a $0.5 \mathrm{M} \mathrm{NaOH}$ solution and filtered with the help of a $0.2 \mu \mathrm{m}$ filter. The HPLC analysis was performed with a Hitachi Chromaster 3000 series HPLC system (Hitachi, Tokyo, Japan), using a diode array detector (DAD) at $260 \mathrm{~nm}$ and a Cosmosil C18 (300 mm length $\times 4.6 \mathrm{~mm}$ ID, pore size: $5 \mu \mathrm{m}$ ) column. The mobile phase consisted of methanol and acetic acid (ratio of 99:1) in an isocratic elution for $30 \mathrm{~min}$ (flow rate: $0.5 \mathrm{ml} / \mathrm{min}$, injection volume: $10 \mu \mathrm{l}$, and column temperature: $25^{\circ} \mathrm{C}$ ). The purity of melanin was calculated from the area under the curve of the HPLC chromatogram. The experiment was repeated thrice with independent preparations.

\section{FTIR and NMR analysis}

For fourier-transform infrared spectroscopy (FTIR) analysis, two milligrams of the dried pigment were ground properly with infra-red grade $\mathrm{KBr}(1: 10)$ and pressed into a disc under vacuum (Al Khatib et al. 2018). The spectrum from 4500 to $400 \mathrm{~cm}^{-1}$ was recorded in a Perkin Elmer Inc. spectrophotometer. The pigment composition and structure were predicted by searching the spectrum against a database of reference spectra.

For proton nuclear magnetic resonance spectroscopy (NMR) analysis, the method of Kurian and Bhat (2017) was followed. The pigment was dissolved in deuterated DMSO and the solution was subjected to ${ }^{1} \mathrm{H}$ NMR analysis using a Bruker $300 \mathrm{MHz}$ instrument with a magnetic field of 11.4 Tesla.

\section{Laccase assay}

Qualitative screening was done by inoculating a $5 \mathrm{~mm}$ diameter mycelial disc of 5-day old culture onto PDA plates containing $4 \mathrm{mM}$ guaiacol (Bodke et al. 2012). Intense brown coloration around the fungal colony was considered positive for laccase production.

For laccase quantification, a mycelial disc from each of the interacting fungi was inoculated into a $250 \mathrm{~mL}$ Erlenmeyer flask containing yeast extract powder $(1 \mathrm{~g} / \mathrm{L})$, D-glucose $(10 \mathrm{~g} / \mathrm{L}), \quad \mathrm{KH}_{2} \mathrm{PO}_{4}(1 \mathrm{~g} / \mathrm{L}), \quad \mathrm{MgSO}_{4} \cdot 7 \mathrm{H}_{2} \mathrm{O}$ $(5 \mathrm{~g} / \mathrm{L}), \mathrm{NaCl}(5 \mathrm{~g} / \mathrm{L})$, lignin $(0.1 \mathrm{~g} / \mathrm{L})$ and incubated at $28{ }^{\circ} \mathrm{C}$ with $150 \mathrm{rpm}$ for 14 days (Vantamuri and Kaliwal 2016). A flask containing the media without inoculum was taken as control. A reaction mixture containing $10 \mathrm{mM}$ sodium acetate buffer ( $\mathrm{pH} 4.5), 0.15 \mathrm{mM}$ Diammonium 2, 2'-azino-bis (3-ethylbenzothiazoline-6-sulfonate) (ABTS), and $0.1 \mathrm{~mL}$ of extract incubated at $30{ }^{\circ} \mathrm{C}$ for $10 \mathrm{~min}$. Oxidation of ABTS was monitored periodically for 14 days by measuring the increase in absorbance at $420 \mathrm{~nm}$ in an Evolution $202 \mathrm{UV}$ vis spectrophotometer (Thermo Scientific, MA, USA). One enzyme unit is defined as the amount of enzyme that oxidizes $1 \mu \mathrm{mol}$ of ABTS per min.

\section{Superoxide dismutase (SOD) assay}

Superoxide dismutase activity was monitored by following the protocol of Debona et al. (2014). Mycelia from the interacting zone was weighed and crushed in phosphate buffer ( $\mathrm{pH} 7.8$ ). SOD activity was assayed on the basis of its ability to inhibit the photochemical reduction 
of nitro-blue tetrazolium (NBT). A reaction mixture containing $50 \mathrm{mM}$ phosphate buffer $(\mathrm{pH} 7.8), 13 \mathrm{mM}$ methionine, $75 \mathrm{mM}$ NBT, $2 \mathrm{mM}$ riboflavin, $0.1 \mathrm{mM}$ EDTA, and $100 \mu \mathrm{L}$ of extract incubated in light for $30 \mathrm{~min}$ was used to perform the assay. Controls which were incubated in dark were maintained for each set. Spectrophotometric readings were taken at $460 \mathrm{~nm}$ periodically for 14 days post inoculation.

\section{Quantitative real-time PCR (qRT-PCR) analysis of associated genes}

A total of 14 test genes and one housekeeping gene were selected for analyzing their expression at transcript levels by qRT-PCR during the interaction of $T$. coccinea versus T. versicolor. Primers used in this study along with their target genes are listed in Additional file 1: Table S1. On the 8th day of interaction, total RNA of T. coccinea versus T. versicolor and their monocultures were isolated using TRI Reagent ${ }^{\circledR}$ (Sigma-Aldrich, MO, USA). The isolated RNA samples were treated with DNase I (Thermo Fisher Scientific, Waltham, MA, USA) and purified using silica column (Life Technologies, Carlsbad, CA, USA). First strand cDNA was prepared from the isolated RNA using GoScript ${ }^{\mathrm{TM}}$ Reverse Transcription kit (Promega, Madison, WI, USA). Quantitative real-time PCR was performed on the first strand cDNA using GoTaq qPCR Master Mix (Promega, Madison, WI, USA) in a total reaction volume of $20 \mu \mathrm{L}$ containing $10 \mathrm{nM}$ of each primer and $50 \mathrm{ng}$ cDNA template according to the manufacturer's protocol. Real-time PCR was performed using three biological replicates on the Quant studio 5 Real-Time PCR System (Applied Biosystems, Foster City, CA, USA) with alphatubulin $(a t n)$ gene as the reference gene. The relative gene expression of each gene was determined using the $2^{-\Delta \Delta C t}$ method (Livak and Schmittgen 2001).

\section{Statistical analysis}

The data obtained from laccase and SOD assay were analyzed in SPSS 25.0 software by one-way Analysis of Variance (ANOVA). Duncan test was performed to study the level of significance $(p \leq 0.05)$. The results of quantitative Real-time PCR were analyzed using student $t$-test in Origin Pro 6.0 and $p \leq 0.05$ was considered as significant.

\section{Results}

\section{SEM analysis during in vitro fungal-fungal interaction}

The SEM analysis for the interaction between $T$. coccinea and L. lactinea as well as T. coccinea and T. versicolor on the late stages of interaction, i.e., on the 9th, 12th and 15th days of interaction showed formation of pores on the hyphae, which was not observed for the monocultures of T. versicolor, T. coccinea and L. lactinea (Fig. 2). The number of pores increased with the increase in number of days of interaction, which ultimately led to the death of the hyphae in the interaction zone.

\section{Metabolite profiling by LC-MS}

The metabolic profiling during the interaction of T. coccinea with $T$. versicolor along with that of the monocultures, i.e., T. coccinea and T. versicolor (Table 1) resulted in identification of 39 compounds. During the interaction 17 compounds are produced; 8 compounds were produced exclusively by $T$. coccinea monoculture and 13 were produced exclusively by $T$. versicolor monoculture. Only one compound was common between $T$. coccinea and its interaction with $T$. versicolor. Similarly, the metabolic profiling during the interaction of $T$. coccinea with $L$. lactinea along with that of the monocultures, i.e., $T$. coccinea and L. lactinea (Table 2) revealed the presence of 39 compounds, of which 19 compounds were produced exclusively during the interaction, 8 compounds were produced by $T$. coccinea and 10 compounds were produced by $L$. lactinea. Two compounds were common for $T$. coccinea and its interaction with L. lactinea. The result showed that more numbers of compounds were obtained from the barrage zone as compared to the monocultures indicating the induction of metabolite production during the interaction process. One of the significant results obtained from the LCMS and HRMS analysis is the detection of compounds like tyrosine, L-DOPA and melanin in the barrage zone (Additional files 2, 3, 4, 5: Figs. S1, S2A, S2B, S2C). Tyrosine and L-DOPA are involved in melanin synthesis pathway (Blagoeva 1984; Rzepka et al. 2016).

\section{Extraction of extracellular melanin pigment}

The SB broth where the two different fungi were dual cultured (i.e., T. coccinea and T. versicolor (Fig. 3A); T. coccinea and L. lactinea (Fig. 3B) showed dark brown coloration. On the other hand, no dark brown coloration was observed in the control and the monocultures of $T$. coccinea, T. versicolor, and L. lactinea. As the color of the culture supernatant in control remained unchanged, it could be assumed that the dark coloration in the interaction culture was due to the compounds secreted by the fungi and not due to the result of the oxidation of the media components. An amount of $37 \mathrm{mg} / \mathrm{L}$ and $31 \mathrm{mg} / \mathrm{L}$ of extracellular pigment were obtained as a product from the culture broth, where T. coccinea-T. versicolor and $T$. coccinea-L. lactinea were allowed to interact respectively.

\section{Biochemical analysis of the melanin pigment}

The solubility test of the pigment showed that it was insoluble in water and organic solvents like ethanol, hexane, and acetone but soluble in $1 \mathrm{M} \mathrm{KOH}$ and $1 \mathrm{M}$ 

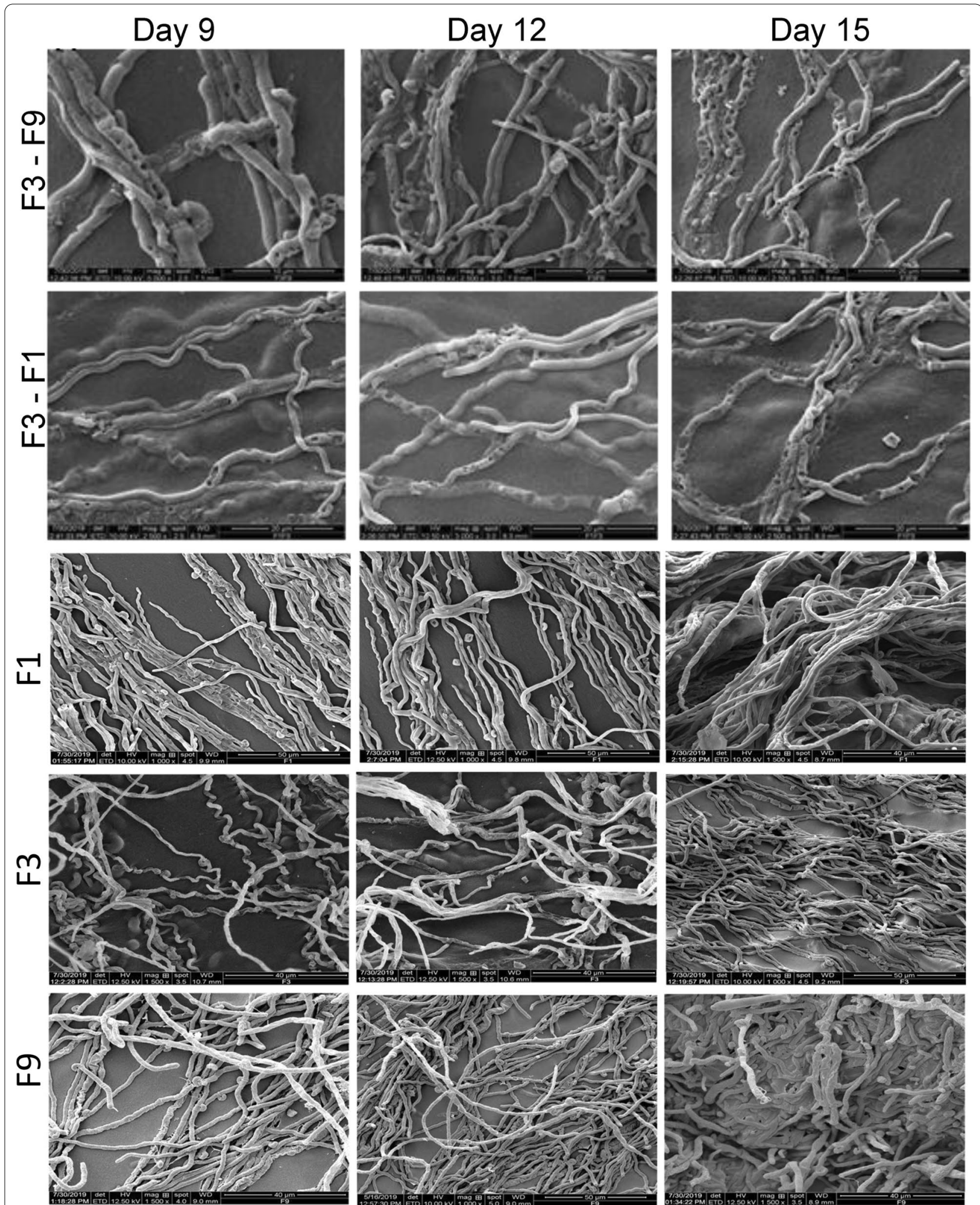

Fig. 2 Scanning electron microscopic observations during interaction. SEM images during the interaction of T. coccinea with L. lactinea, T. coccinea with T. versicolor and the monocultures of T. versicolor, T. coccinea, L. lactinea respectively on 9th, 12th, and 15th days after inoculation 
Table 1 Comparative analysis of metabolite profiles during interspecific interactions between T. coccinea-T. versicolor

\begin{tabular}{|c|c|c|c|c|c|c|}
\hline $\begin{array}{l}\text { Retent } \\
\text { ion } \\
\text { time }\end{array}$ & $\begin{array}{c}\text { Predicte } \\
d \\
\text { molecula } \\
\text { r mass }\end{array}$ & Adduct & $\begin{array}{c}T . \\
\text { cocci } \\
\text { nea }\end{array}$ & $\begin{array}{c}\text { T. } \\
\text { versic } \\
\text { olor }\end{array}$ & $\begin{array}{c}T . \\
\text { coccinea- } \\
T . \\
\text { versicolor }\end{array}$ & Compound \\
\hline 1.09 & 157.1 & $158.1(\mathrm{M}+\mathrm{H})$ & + & - & - & $\mathrm{N}$-acetyl-D-proline \\
\hline 1.13 & 117.1 & $118.1(\mathrm{M}+\mathrm{H})$ & - & + & - & $\begin{array}{l}\text { L-aspartic 4- } \\
\text { semialdehyde }\end{array}$ \\
\hline 1.44 & 286.2 & $287.2(\mathrm{M}+\mathrm{H})$ & + & - & - & Cinnabarin \\
\hline 1.59 & 300.1 & $301.1(\mathrm{M}+\mathrm{H})$ & + & - & + & Cinnabarinic acid \\
\hline 2.29 & 147.9 & $148.9(\mathrm{M}+\mathrm{H})$ & - & - & + & Unknown \\
\hline 5.67 & 147.1 & $148.1(\mathrm{M}+\mathrm{H})$ & - & + & - & Unknown \\
\hline \multicolumn{7}{|l|}{$\begin{array}{l}7.72(\mathrm{P} \\
\mathrm{DA})\end{array}$} \\
\hline 7.56 & 278.1 & $\begin{array}{l}279.1 \\
(\mathrm{M}+\mathrm{H}) \\
301.0 \\
(\mathrm{M}+\mathrm{Na})\end{array}$ & - & - & + & Unknown \\
\hline 7.74 & 240.2 & $241.2(\mathrm{M}+\mathrm{H})$ & - & + & - & Anserine \\
\hline 8.74 & 285.3 & $286.3(\mathrm{M}+\mathrm{H})$ & - & + & - & Unknown \\
\hline 9.92 & 421.5 & $422.5(\mathrm{M}+\mathrm{H})$ & - & - & + & Unknown \\
\hline 10.31 & 313.3 & $314.3(\mathrm{M}+\mathrm{H})$ & - & + & - & Unknown \\
\hline 11.19 & 218.2 & $219.2(\mathrm{M}+\mathrm{H})$ & - & - & + & Unknown \\
\hline 11.21 & 278.9 & $279.9(\mathrm{M}+\mathrm{H})$ & - & + & - & Unknown \\
\hline \multicolumn{7}{|l|}{$\begin{array}{l}11.37( \\
\text { PDA) }\end{array}$} \\
\hline 11.77 & 229.3 & $230.3(\mathrm{M}+\mathrm{H})$ & - & + & - & Unknown \\
\hline 12.14 & 273.3 & $274.4(\mathrm{M}+\mathrm{H})$ & - & + & - & Unknown \\
\hline 12.18 & 226.5 & $227.5(\mathrm{M}+\mathrm{H})$ & - & - & + & Unknown \\
\hline 12.84 & 299.3 & $300.3(\mathrm{M}+\mathrm{H})$ & - & + & - & $\begin{array}{l}\text { 4-amino-2-methyl-5- } \\
\text { diphosphopyrimidine }\end{array}$ \\
\hline 13.96 & 285.3 & $286.3(\mathrm{M}+\mathrm{H})$ & - & + & - & $\begin{array}{l}\beta \text {-Alanine, N- } \\
\text { isobutyryl-, decyl ester }\end{array}$ \\
\hline 14.19 & 583.2 & $584.2(\mathrm{M}+\mathrm{H})$ & - & - & + & Unknown \\
\hline 14.71 & 197.2 & $198.2(\mathrm{M}+\mathrm{H})$ & - & - & + & L-DOPA \\
\hline 15.60 & 183.2 & $184.2(\mathrm{M}+\mathrm{H})$ & + & - & - & Phenoxazine \\
\hline 15.73 & 313.3 & $314.3(\mathrm{M}+\mathrm{H})$ & - & + & - & Unknown \\
\hline 16.39 & 240.3 & $241.3(\mathrm{M}+\mathrm{H})$ & - & - & + & D-Cystine \\
\hline 16.56 & 170.1 & $171.1(\mathrm{M}+\mathrm{H})$ & - & - & + & $\begin{array}{l}\text { D-Glyceraldehyde 3- } \\
\text { phosphate }\end{array}$ \\
\hline 17.01 & 181.2 & $182.2(\mathrm{M}+\mathrm{H})$ & - & - & + & Tyrosine \\
\hline 18.48 & 300.9 & $301.9(\mathrm{M}+\mathrm{H})$ & - & - & + & Unknown \\
\hline 18.73 & 633.3 & $634.3(\mathrm{M}+\mathrm{H})$ & - & - & + & Unknown \\
\hline 19.44 & 338.6 & $339.6(\mathrm{M}+\mathrm{H})$ & + & - & - & Oleic acid, butyl ester \\
\hline 19.87 & 356.4 & $357.4(\mathrm{M}+\mathrm{H})$ & + & - & - & Unknown \\
\hline 20.00 & 506.2 & $507.2(\mathrm{M}+\mathrm{H})$ & - & - & + & Unknown \\
\hline 20.81 & 318.3 & $319.3(\mathrm{M}+\mathrm{H})$ & - & - & + & Melanin \\
\hline 21.76 & 427.4 & $428.4(\mathrm{M}+\mathrm{H})$ & + & - & - & Unknown \\
\hline 21.97 & 474.2 & $475.2(\mathrm{M}+\mathrm{H})$ & - & - & + & Unknown \\
\hline 24.25 & 336.3 & $337.3(\mathrm{M}+\mathrm{H})$ & - & + & - & $\begin{array}{l}\text { S- } \\
\text { (Hydroxymethyl)glutat } \\
\text { hione }\end{array}$ \\
\hline 24.52 & 351.3 & $352.3(\mathrm{M}+\mathrm{H})$ & - & - & + & Unknown \\
\hline 24.70 & 355.4 & $356.4(\mathrm{M}+\mathrm{H})$ & + & - & - & $\begin{array}{l}\text { S- } \\
\text { Adenosylmethioninam } \\
\text { ine }\end{array}$ \\
\hline 24.87 & 385.3 & $386.3(\mathrm{M}+\mathrm{H})$ & - & + & - & Unknown \\
\hline 25.89 & 240.1 & $241.2(\mathrm{M}+\mathrm{H})$ & - & - & + & Unknown \\
\hline 26.22 & 455.4 & $456.4(\mathrm{M}+\mathrm{H})$ & + & - & - & Unknown \\
\hline
\end{tabular}


Table 1 (continued)

The '+' sign indicates presence and the' - ' sign indicates absence of a particular compound. The orange-coloured cells are for the compounds produced exclusively by T. coccinea; the blue-coloured cells are for the compounds produced exclusively by T. versicolor; the yellow-coloured cells are for the compounds present in either or both the monocultures and in the interaction zone, the green-coloured cells are for the compounds produced exclusively in the interaction zone; the grey-coloured cells are for the components of PDA that has been omitted for analysis

$\mathrm{NaOH}$. Also, the brown coloration of the pigment faded away when it was treated with an oxidizing agent like hydrogen peroxide. Treatment of melanin with hydrochloric acid resulted in precipitate formation (Table 3).

\section{HPLC analysis}

The High-Performance Liquid Chromatography analysis showed that the chromatograms of synthetic melanin and brown pigment extracted from the barrage zones are composed of a single major signal with $>90 \%$ purity. The retention time is $\sim 5.06$ min for both synthetic- and fungal- melanin (Additional file 6: Fig. S3).

\section{Characterization of the melanin pigment from FTIR spectrum}

In FTIR spectrum, peaks were obtained at $3399 \mathrm{~cm}^{-1}$, $2,926 \mathrm{~cm}^{-1}, 2,851 \mathrm{~cm}^{-1}, 1,586 \mathrm{~cm}^{-1}, 1385 \mathrm{~cm}^{-1}$, $1030 \mathrm{~cm}^{-1}$ and $618 \mathrm{~cm}^{-1}$. Absorption at $3399 \mathrm{~cm}^{-1}$ attributes to the polymeric $\mathrm{OH}$ groups. The stretching vibrations for aliphatic $\mathrm{CH}$ bonding appear at $2926 \mathrm{~cm}^{-1}$ and $2851 \mathrm{~cm}^{-1}$. At $1586 \mathrm{~cm}^{-1}$, the symmetric carboxylate stretching vibrations (COO) are detectable. The indole ring vibration/CNC stretching was observed at $1385 \mathrm{~cm}^{-1}$. $\mathrm{CH}$ in-plane $/ \mathrm{CH}$ out-of plane deformation are attributed at $1030 \mathrm{~cm}^{-1} .618 \mathrm{~cm}^{-1}$ indicates to the out-of-plane bending of the aromatic carbon-hydrogen bond (Fig. 4A). The presence of these functional groups indicates the presence of melanin.

\section{Characterization of the melanin pigment from NMR spectrum}

In NMR spectrum, peaks were obtained at $0.814 \mathrm{ppm}$, $0.837 \mathrm{ppm}, 0.851,1.150 \mathrm{ppm}, 1.231 \mathrm{ppm}, 2.369 \mathrm{ppm}$, $2.508 \mathrm{ppm}, 2.643 \mathrm{ppm}, 3.454 \mathrm{ppm}$ and $7.222 \mathrm{ppm}$. 0.814$1.150 \mathrm{ppm}$ can be attributed to the $\mathrm{CH}_{3}$ groups of alkyl fragments. Peak at $1.231 \mathrm{ppm}$ can be attributed to the long chain methylenes. Peak at $2.369 \mathrm{ppm}$ is associated with the $\mathrm{CH}$ at aliphatic region. The signal at $2.508 \mathrm{ppm}$ is associated with DMSO, which comes from the solvent deuterated DMSO or sulfonate groups bound to the pyrrole nitrogen which is relative to the occurrence of $\mathrm{N}$-sulfonation. Peak at 7.222 ppm is related to the pyrrole $-\mathrm{CH}$ group of a carboxyl substituted indole. A peak ranging at $3.454 \mathrm{ppm}$ is also observed tentatively near the signal from residual water in the DMSO. Peak at $2.643 \mathrm{ppm}$ indicates $\mathrm{CH}_{2} \mathrm{CO}$ group (Fig. 4B). The presence of these functional groups infers the compound to be melanin.

\section{Assessment of laccase activity during in vitro fungal-fungal interaction}

Qualitative analysis of laccase activity through plate assay indicated $T$. coccinea, $T$. versicolor and L. lactinea to be laccase positive (Fig. 5 and Additional file 7). Quantification of laccase activity revealed that the interactions increased laccase activities as compared to the enzyme activity in pure cultures. The laccase activity increased from 2nd day post inoculation up to the 8th day, and then slightly decreased on the succeeding days until the 14th day post inoculation for both the interactions (Fig. 6A, B). The laccase activity in case of the pure cultures also increased till the 8th days post inoculation but was less (significantly low), compared to the interaction ones. The laccase activity for $T$. coccinea with $T$. versicolor (F3-F1) and $T$. coccinea with L. lactinea (F3-F9) in the interaction zone was found to be $253.86 \mathrm{U} / \mathrm{L}$ and $272.25 \mathrm{U} / \mathrm{L}$ respectively. This was more as compared to the laccase activity of the monocultures of $T$. coccinea, $T$. versicolor and L. lactinea was found to be $70.64 \mathrm{U} / \mathrm{L}, 115.03 \mathrm{U} / \mathrm{L}$ and $134.42 \mathrm{U} / \mathrm{L}(p \leq 0.05)$.

\section{Assessment of superoxide dismutase (SOD) activity during in vitro fungal-fungal interaction}

The superoxide dismutase assay showed that during the initial days of interaction (4th, 6th and 8th days) the superoxide dismutase activity was higher for the interacting fungi. But their activity gradually decreased from the 10 th day post inoculation. Superoxide dismutase activity was very negligible as observed for the monocultures i.e., $1.5 \mathrm{U} / \mathrm{mgFW}$ in $T$. coccinea, $0.57 \mathrm{U} / \mathrm{mgFW}$ in T. versicolor and $0.79 \mathrm{U} / \mathrm{mgFW}$ in L. lactinea (Additional file 7). The SOD activity for $T$. coccinea with $T$. versicolor (F3-F1) and $T$. coccinea with L. lactinea (F3-F9) in the interaction zone was found to be highest, i.e., 207.81 U/mgFW and $246.74 \mathrm{U} / \mathrm{mgFW}$ respectively at $p \leq 0.05$ (Fig. $6 \mathrm{C}, \mathrm{D}$ ).

\section{Gene expression profile during interaction of $T$. coccinea and $T$. versicolor}

Quantitative Real time PCR (qRT-PCR) analysis of the 14 genes during interaction of $T$. coccinea and $T$. versicolor was performed and compared to the expression profile of $T$. versicolor control culture to understand how the interaction of the two fungal isolates affect the 
Table 2 Comparative analysis of metabolite profiles during interspecific interactions between T. coccinea-L. lactinea

\begin{tabular}{|c|c|c|c|c|c|c|}
\hline $\begin{array}{l}\text { Retenti } \\
\text { on time }\end{array}$ & $\begin{array}{c}\text { Predicte } \\
\mathbf{d} \\
\text { molecul } \\
\text { ar mass }\end{array}$ & Adduct & $\begin{array}{c}T . \\
\text { coccinea }\end{array}$ & $\begin{array}{c}L . \\
\text { lactinea }\end{array}$ & $\begin{array}{c}\text { T. coccinea } \\
-L . \\
\text { lactinea }\end{array}$ & Compound \\
\hline 1.09 & 157.1 & $158.1(\mathrm{M}+\mathrm{H})$ & + & - & - & Unknown \\
\hline 1.13 & 141.2 & $142.1(\mathrm{M}+\mathrm{H})$ & - & - & + & Unknown \\
\hline 1.44 & 286.2 & $287.2(\mathrm{M}+\mathrm{H})$ & + & - & - & Cinnabarin \\
\hline 1.48 & 143.0 & $144.0(\mathrm{M}+\mathrm{H})$ & - & - & + & Unknown \\
\hline 1.59 & 300.1 & $301.1(\mathrm{M}+\mathrm{H})$ & + & - & + & Cinnabarinic acid \\
\hline 2.12 & 292.1 & $293.1(\mathrm{M}+\mathrm{H})$ & - & - & + & Unknown \\
\hline 7.70 & 240.2 & $241.3(\mathrm{M}+\mathrm{H})$ & + & - & + & Anserine \\
\hline 7.79 & 286.1 & $287.1(\mathrm{M}+\mathrm{H})$ & - & - & + & Unknown \\
\hline 8.95 & 150.2 & $151.2(\mathrm{M}+\mathrm{H})$ & - & - & + & Tartaric acid \\
\hline 10.77 & 148.1 & $171.1(\mathrm{M}+\mathrm{Na})$ & - & + & - & 2-hydroxy glutaric acid \\
\hline $\begin{array}{l}11.16 \\
\text { (PDA) }\end{array}$ & & & & & & \\
\hline 11.19 & 278.1 & $279.1(\mathrm{M}+\mathrm{H})$ & - & - & + & Unknown \\
\hline 11.35 & 277.1 & $278.1(\mathrm{M}+\mathrm{H})$ & - & + & - & Unknown \\
\hline 11.64 & 229.2 & $230.2(\mathrm{M}+\mathrm{H})$ & - & - & + & Unknown \\
\hline 13.32 & 414.2 & $415.2(\mathrm{M}+\mathrm{H})$ & - & - & + & Unknown \\
\hline $\begin{array}{l}14.17 \\
\text { (PDA) }\end{array}$ & & & & & & \\
\hline $\begin{array}{l}14.69 \\
\text { (PDA) }\end{array}$ & & & & & & \\
\hline 14.71 & 197.2 & $198.2(\mathrm{M}+\mathrm{H})$ & - & - & + & L-DOPA \\
\hline 14.88 & 476.5 & $477.5(\mathrm{M}+\mathrm{H})$ & - & - & + & Unknown \\
\hline 15.58 & 226.1 & $227.1(\mathrm{M}+\mathrm{H})$ & - & + & - & Chorismate \\
\hline 15.60 & 183.2 & $184.2(\mathrm{M}+\mathrm{H})$ & + & - & - & Phenoxazine \\
\hline 16.58 & 575.3 & $576.3(\mathrm{M}+\mathrm{H})$ & - & + & - & Unknown \\
\hline 17.01 & 181.2 & $182.2(\mathrm{M}+\mathrm{H})$ & - & - & + & Tyrosine \\
\hline 18.44 & 382.2 & $383.2(\mathrm{M}+\mathrm{H})$ & - & + & - & Unknown \\
\hline 18.48 & 383.0 & $384.0(\mathrm{M}+1)$ & - & - & + & Unknown \\
\hline 18.71 & 476.0 & $477.0(\mathrm{M}+\mathrm{H})$ & - & + & - & Unknown \\
\hline 18.73 & 677.3 & $678.3(\mathrm{M}+\mathrm{H})$ & - & - & + & Unknown \\
\hline 19.44 & 338.3 & $339.3(\mathrm{M}+\mathrm{H})$ & + & - & - & Unknown \\
\hline 19.87 & 354.3 & $355.3(\mathrm{M}+\mathrm{H})$ & + & - & - & Unknown \\
\hline 19.98 & 324.3 & $325.3(\mathrm{M}+\mathrm{H})$ & - & + & - & Unknown \\
\hline 20.74 & 318.3 & $319.3(\mathrm{M}+\mathrm{H})$ & - & - & + & Melanin \\
\hline 21.76 & 427.4 & $428.4(\mathrm{M}+\mathrm{H})$ & + & - & - & Unknown \\
\hline 21.97 & 484.3 & $485.3(\mathrm{M}+\mathrm{H})$ & - & - & + & Unknown \\
\hline 22.51 & 397.4 & $398.4(\mathrm{M}+\mathrm{H})$ & - & - & + & Unknown \\
\hline 22.86 & 383.4 & $384.4(\mathrm{M}+\mathrm{H})$ & - & - & + & Unknown \\
\hline 24.48 & 281.3 & $282.3(\mathrm{M}+\mathrm{H})$ & - & - & + & Unknown \\
\hline 24.70 & 355.4 & $356.4(\mathrm{M}+\mathrm{H})$ & + & - & - & $\begin{array}{l}\text { S- } \\
\text { Adenosylmethioninamine }\end{array}$ \\
\hline 24.75 & 382.5 & $383.5(\mathrm{M}+\mathrm{H})$ & - & + & - & Unknown \\
\hline 25.45 & 390.3 & $391.3(\mathrm{M}+\mathrm{H})$ & - & + & - & Unknown \\
\hline 25.70 & 396.3 & $397.3(\mathrm{M}+\mathrm{H})$ & - & - & + & Unknown \\
\hline 26.22 & 455.4 & $456.4(\mathrm{M}+\mathrm{H})$ & + & - & - & Unknown \\
\hline 26.28 & 535.3 & $536.3(\mathrm{M}+\mathrm{H})$ & - & + & - & Unknown \\
\hline
\end{tabular}


Table 2 (continued)

The '+'sign indicates presence and the '-'sign indicates absence of a particular compound. The orange-coloured cells are for the compounds produced exclusively by T. coccinea; the blue-coloured cells are for the compounds produced exclusively by L. lactinea; the yellow-coloured cells are for the compounds present in either or both the monocultures and in the interaction zone, the green-coloured cells are for the compounds produced exclusively in the interaction zone; the grey-coloured cells are for the components of PDA that has been omitted for analysis
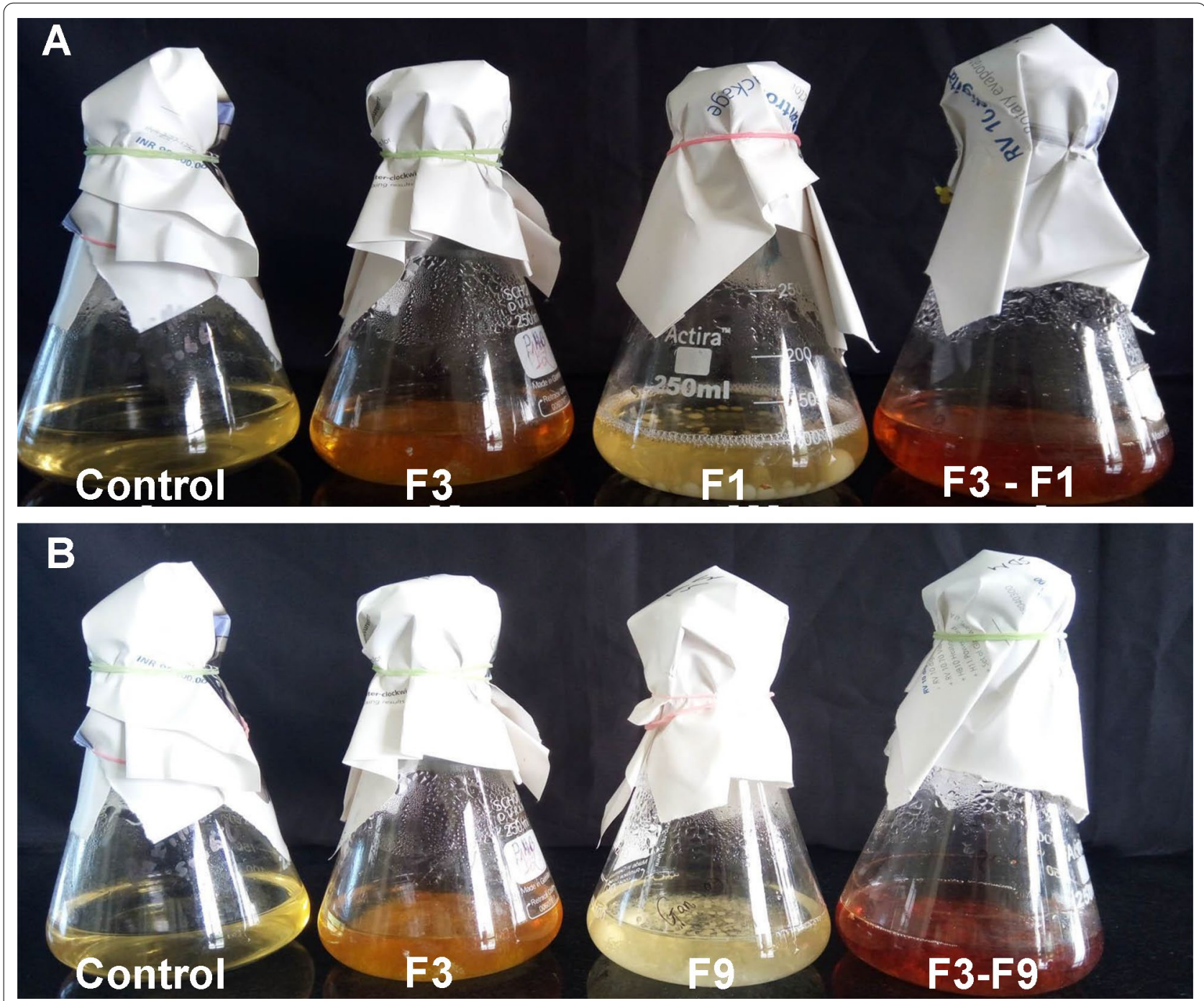

Fig. 3 Culture broth showing melanin production. A, B Dark brown formation in the flask containing the interacting mycelia for T. coccinea versus T. versicolor and $T$. coccinea versus $L$. lactinea respectively

expression of these genes. The results of qRT-PCR analysis are shown in Fig. 7 and Additional file 8. Among the genes that showed upregulation during interaction, the $l c c 1$ gene that encodes laccase showed 11.1-fold increased expression during interaction followed by $t p s$ (6.2-fold), cro (2.8 folds), amnO (1.7-fold) and alcDH (1.6-fold). Among the genes tested, $f d o$ (gene encoding FAD-linked oxidoreductase), $g d c$ (gene encoding glutamate decarboxylase), gst (gene encoding glutathione $\mathrm{S}$ transferase), alcO (gene encoding alcohol oxidase) and $k c t$ (gene encoding 3-ketoacyl-CoA thiolase) showed significantly decrease in expression during interaction. The rest of the genes viz., $a b c T$ (gene encoding an $\mathrm{ABC}$ transporter), acdo (gene encoding aromatic compound dioxygenase), $c m t$ (gene encoding CDF metal transporter), and $m p x$ (gene encoding manganese peroxidase) did not reveal any significant difference in their 
Table 3 Biochemical characterization of melanin

\begin{tabular}{|c|c|c|}
\hline Sl. no & Assay & Result \\
\hline 1 & Solubility in water & Insoluble \\
\hline 2 & Solubility in ethanol & Insoluble \\
\hline 3 & Solubility in hexane & Insoluble \\
\hline 4 & Solubility in acetone & Insoluble \\
\hline 5 & Solubility in $1 \mathrm{M} \mathrm{KOH}$ & Soluble \\
\hline 6 & Solubility in $1 \mathrm{M} \mathrm{NaOH}$ & Soluble \\
\hline 7 & $\begin{array}{l}\text { Reaction with hydrogen per- } \\
\text { oxide }\end{array}$ & Decolorization of the pigment \\
\hline 8 & Reaction with hydrochloric acid & Precipitated readily \\
\hline
\end{tabular}

expression during interaction of $T$. coccinea and $T$. versicolor.

\section{Discussion}

Fungal melanins are secondary metabolite made up of complex heterogeneous polymers of phenolic and/or indole monomers. They are reported to play a myriad of biological roles such as in morphogenesis, virulence, energy transduction including acting as scavengers of stresses, and in turn protect cell viability (Toledo et al. 2017). Previously, brown pigmentation was reported in the barrage zone of fungal interactions due to deposition of certain quinone compounds assumed to be melanin or melanin like compounds and is associated with morphological changes at interacting hyphal fronts (Peiris et al. 2008). However, interesting changes were observed in the present study during deadlock interaction, where the interacting hyphae showed altered hyphal morphology and pigment production. To explore these interactions fully, the changes in hyphal morphology, metabolite production and gene expression were studied. The occurrence of pigmentation in the barrage zone could be correlated to the deposition of melanin pigments which got induced during stress condition due to the physical contact between the competing hyphae. HPLC and LC-MS analysis suggested the presence of melanin as a major compound in the zones of interactions. Biophysical analysis using FTIR and NMR further confirmed that the brown pigment is melanin. The amount of melanin produced during fungal-fungal interaction in the present study was higher $(31-37 \mathrm{mg} / \mathrm{L})$ when compared to the melanin produced by monocultures of different species as compared to the previous study on Schizophyllum commune, which produced only $0.25 \mathrm{mg} / \mathrm{L}$ of melanin from the culture broth (Arun et al. 2015).

Morphological changes were also observed in the zone of interaction which is often related to altered metabolism conferred by various metabolic and oxidative enzymes, increase or decrease of which could lead to a series of other changes. Scanning electron microscopic analysis of fungal hyphae from interaction zone revealed formation of pores on the hyphae of the interacting isolates leading to distortion of the hyphae and culminated in death of hyphae which can be attributed as a characteristic feature of deadlock interaction. In many studies, various authors have mentioned that in case of deadlock interaction, both the interacting fungi compete strongly so that neither of the fungi can acquire the territory of the other (Boddy 2000). One or both of the interacting fungi secrete some important metabolites which results in the death of the interacting hyphae in the interaction zone (Peiris et al. 2008). Therefore, the changes in metabolite profile during the interaction of $T$. coccinea with $T$. versicolor and $T$. coccinea with $L$. lactinea was analyzed. The metabolic profile revealed that during the interaction process many compounds were synthesized or induced which were otherwise not produced by the mono cultures. The presence of compounds like tyrosine and L-DOPA could be co-related to the production of melanin-an important bioactive molecule (Slominski et al. 2012; Luo et al. 2017; Almeida-Paes et al. 2018).

In general, there is also a possibility of competition between fungal species for nutritional and habitat resources resulting in the induction of stress related compounds as well as laccase activity (Gregorio et al. 2006). The enzyme is also reported to play a crucial role in detoxification. The increase in laccase activity in the interaction zone may be due to the defense reaction resulting from mycelial confrontations (Baldrian 2004). Eyre et al. (2010) reported that enzymes involved in reactive oxygen species (ROS) generation, like the NADPH oxidases, laccase and peroxidases are occasionally upregulated during interaction. Accumulation of ROS in barrage zones causes oxidative damage to competitor mycelia, particularly in the deadlock ones. Laccase not only could function as antioxidants to remove ROS for fungal survival, but also showed a strong ability of xenobiotic detoxification as reported earlier (Zhong et al. 2019). In the present study, the increase in superoxide dismutase in the early days of post inoculation indicates the increase production of ROS. Reports suggested that ROS production increases in the interaction zone due to oxidative stress during the interaction of Dichomitus squalens and $P$. ostreatus. This increase in ROS production results in the activation of first line of defense by enhancing the activity of superoxide dismutase which helps in scavenging the ROS compounds (Tamayo et al. 2016).

Morphological changes are associated with changes in gene expression compared to non-interacting mycelia during interactions. For example, during antagonistic interaction, downregulation of chitin synthase 

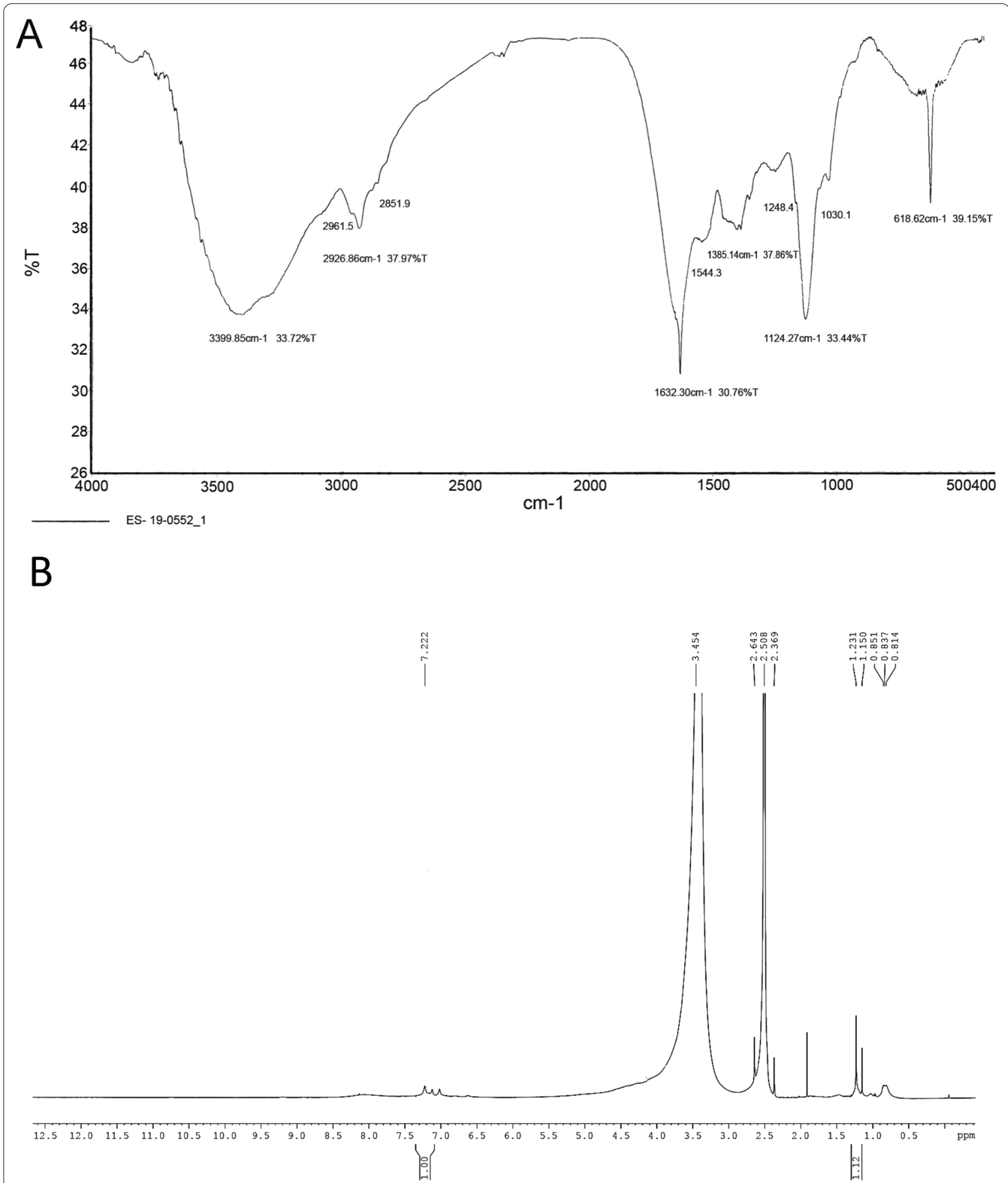

Fig. 4 Spectroscopic characterization of melanin pigment purified from T. coccinea-T. versicolor culture. A FTIR spectrum. B NMR spectrum 

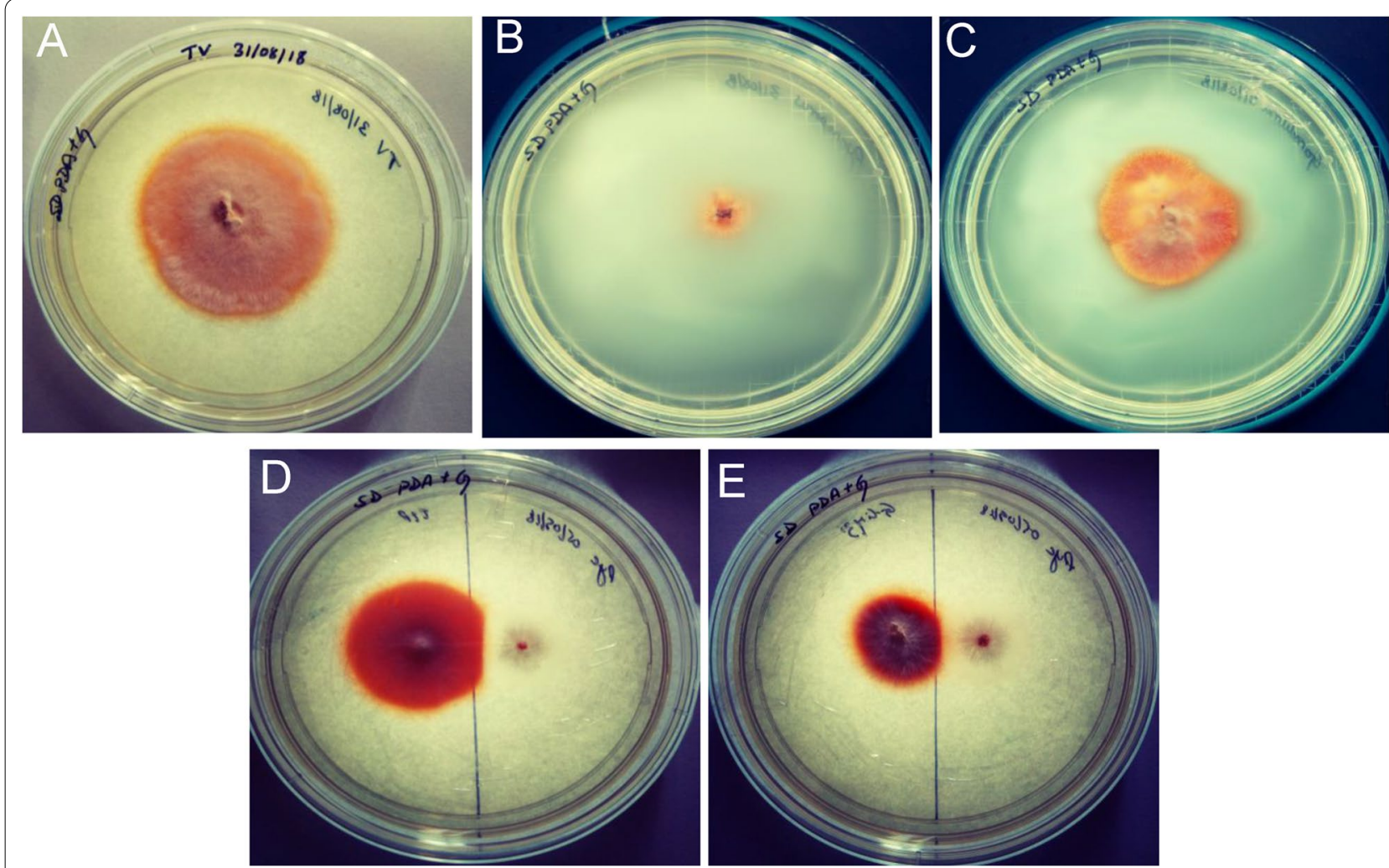

Fig. 5 Qualitative laccase activity for plate cultures. A T. versicolor (F1). B T. coccinea (F3). C L. lactinea (F9). D T. coccinea versus T. versicolor. E T. coccinea versus L. lactinea

in S. gausapatum; there is decrease in growth with its possible replacement by $T$. versicolor (Eyre et al. 2010). Quantitative real-time PCR suggested that several stress related genes from $T$. versicolor were differentially expressed during the interaction process. We could not study the differential gene expression of $T$. coccinea during interaction due to the unavailability of completely annotated genome sequence of $T$. coccinea. The $l c c 1$ gene of $T$. versicolor, which encodes the laccase enzyme showed significant upregulation $(p \leq 0.05)$ compared to the monoculture. Laccases have been reported earlier to be involved in melanin production (Boddy and Hiscox 2016). Although many studies have revealed that interspecific fungal interactions contribute to the increase in laccase activity, (Baldrian 2004; Chi et al. 2007; Gregorio et al. 2006; Hiscox et al. 2010; Kuhar et al. 2015; Wei et al. 2010) the mechanism of laccase production caused by mycelial interactions still remains elusive. Here, the production of melanin in the interaction culture (as revealed by LC-MS, FTIR and NMR analysis) could be correlated to the high laccase activity, which was due to the upregulation of $l c c 1$ gene. Other oxidative stress related genes, such as tps (gene encoding terpenoid synthase), cro (gene encoding copper radical oxidase), $a m n O$ (gene encoding amine oxidase) and alcDH (gene encoding alcohol dehydrogenase) were also induced during interaction, which was at par the earlier report (Zhong et al. 2019). Differential expression of these stress related genes indicated the occurrence of stress signals during the interspecific mycelial interaction of the two macrofungal species (Silar 2005).

\section{Conclusion}

The present study revealed that the changes in the hyphal pattern during the fungal interaction among the three white rot fungi are mostly related to the metabolites produced during interaction. An overproduction of the extracellular enzyme laccase during the fungal interaction was also marked to have a role in the detoxification process. This may be due to the production of some toxic compounds or may be due to the production of ROS during interaction by one or both of the interacting fungi. As a result of this, the production of laccase in the interaction zone increases by either or both the fungi. The findings of this study are further supported by the evidence of increase superoxide dismutase activity that acts as a scavenging radical. The 

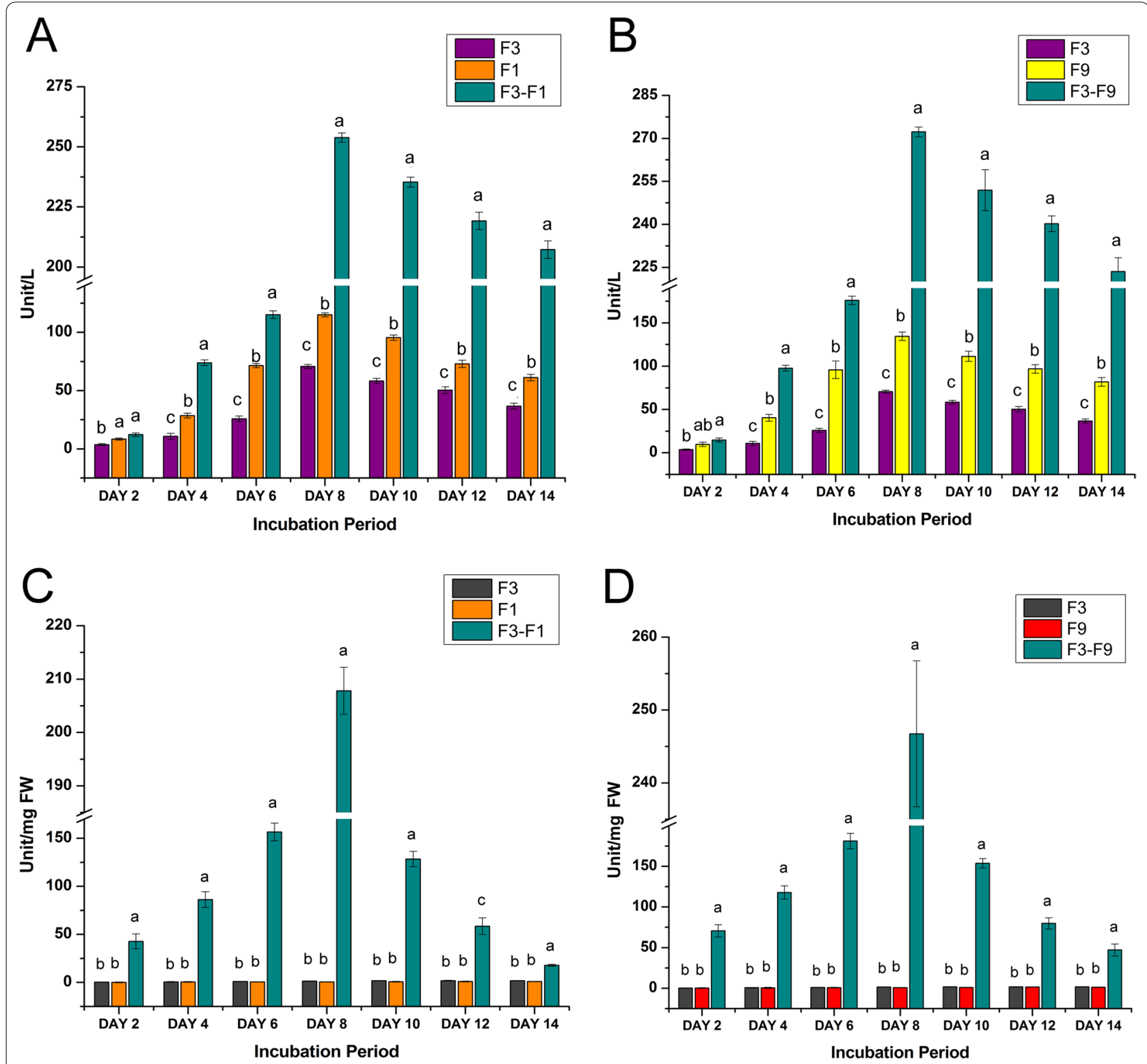

Fig. 6 Quantitative analysis for enzyme production. A Laccase production by T. coccinea (F3), T. versicolor (F1) and their interaction (F3-F1). B Laccase production by T. coccinea (F3), L. lactinea (F9) and their interaction (F3-F9). C SOD production by T. coccinea (F3), T. versicolor (F1) and their interaction (F3-F1). D SOD production by T. coccinea (F3), L. lactinea (F9) and their interaction (F3-F9) (level of significance with $p \leq 0.05$ )

present study analysed differential genes expression during interspecific fungal interactions, revealing that defense-related responses and a myriad of signaling pathways might be associated with the upregulation of oxidative stress-resistant genes, along with the production of an industrially important bioactive compound (melanin), and thereby competing for both nutrient and territory.

Fig. 7 qRT-PCR analysis of T. versicolor (control) and T. coccinea versus T. versicolor (treatment). A Amine oxidase. B FAD—linked oxidoreductase. C Glutamate decarboxylase. D Terpenoid synthase. E Alcohol dehydrogenase. F CDF metal transporter. G Copper radical oxidase. H Glutathione-S-transferase. I Alcohol oxidase. J Laccase. K Manganese peroxidase. L 3-ketoacyl-CoA thiolase. M ABC-transporter. N Alcohol dehydrogenase. Significance was calculated using student's t test with $p \leq 0.05$ 

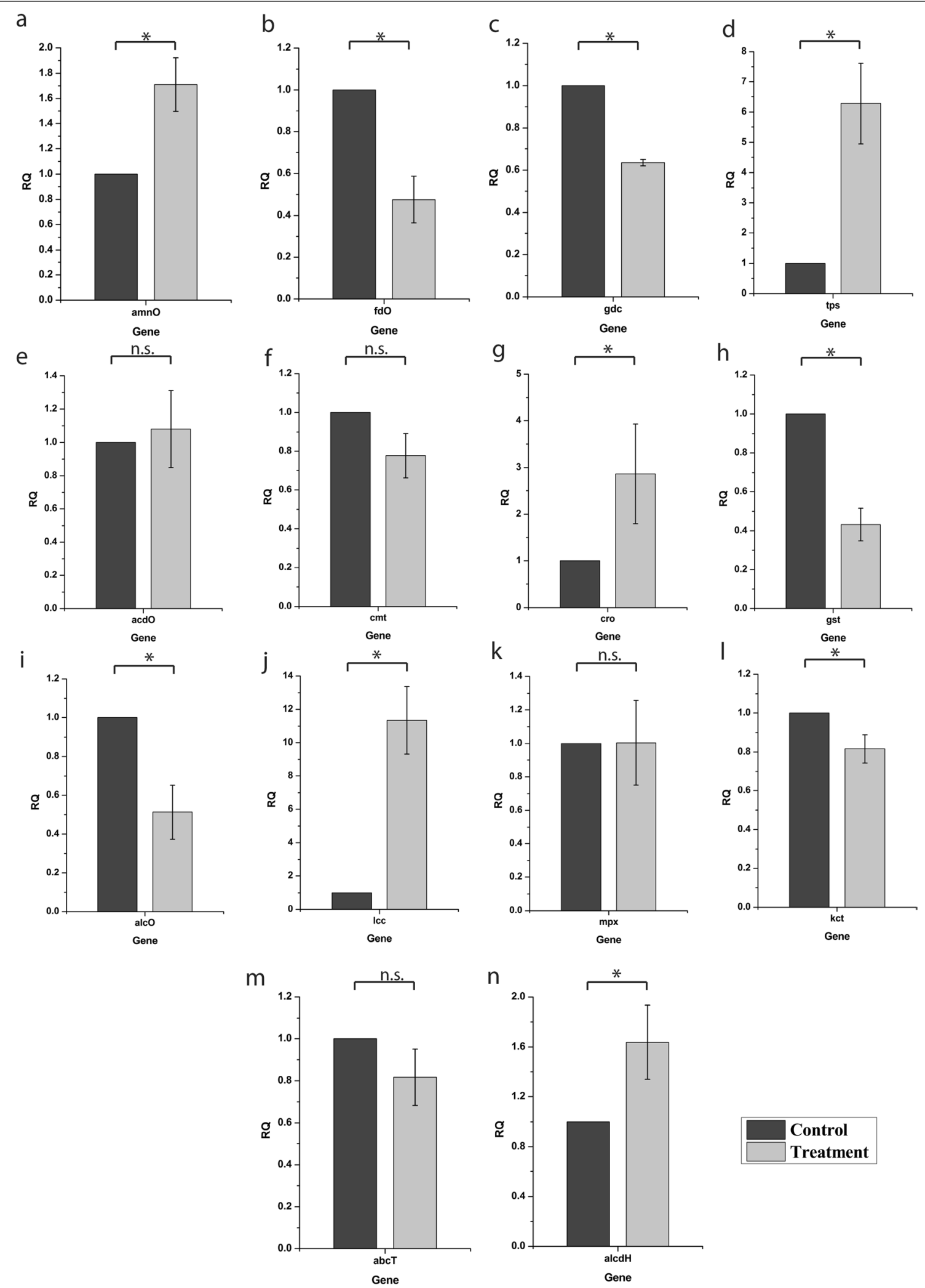

Fig. 7 (See legend on previous page.) 


\section{Supplementary Information}

The online version contains supplementary material available at https://doi. org/10.1186/s43008-021-00082-y.

Additional file 1: Table S1. List of oligonucleotide primers used in the present study.

Additional file 2: Fig. S1. LC-MS chromatogram of the extracts. A. Trametes coccinea. B. Trametes versicolor. C. Leiotrametes lactinea., D. T. coccinea vs. T. versicolor. E. T. coccinea vs. L. lactinea.

Additional file 3: Fig. S2A. HRMS spectra of Tyrosine.

Additional file 4: Fig. S2B. HRMS spectra of L-DOPA.

Additional file 5: Fig. S2C. HRMS spectra of Melanin.

Additional file 6: Fig. S3. TLC analysis of melanin. A. Melanin extracted from fungal dual culture. B. Standard Melanin (Sigma, USA).

Additional file 7: Lacccase and Superoxide dismutase (SOD) activity of $T$. coccinea-T. versicolor and T. coccinea-L. lactinea dual cultures as well as their monocultures.

Additional file 8: Result of qRT-PCR analysis.

\section{Acknowledgements}

Authors are grateful to Department of Agricultural Biotechnology, Assam Agricultural University and DBT-North East Centre for Agricultural Biotechnology for providing instrumentation facility and laboratory space for carrying out the study. SD received Maulana Azad National Fellowship, Ministry of Minority Affairs, UGC, and Government of India for her Ph.D. work. The authors are also grateful to the Science and Engineering Research Board (SERB), Department of Science and Technology (DST), Government of India for funding under the Project Sanction No. EEQ/2016/000631 without any influences in the experimental procedures and results.

\section{Authors' contributions}

$\mathrm{RCB}$ conceived the idea and acquired funding; SD and RCB designed the study; SD performed enzyme assay, scanning electron microscopy, liquid chromatography-mass spectrometry, analyzed the findings and prepared the draft manuscript; DJH, GG and SD designed the primers, interpreted the results and prepared the figures; AG, DJH, GG and TB performed the gene-expression studies; $A B, M B$ and RCB provided the technical support during the study; All authors read the manuscript, critically revised and agreed to the content of the manuscript. All authors read and approved the final manuscript.

\section{Funding}

This work was partially funded by the Science and Engineering Research Board (SERB), Department of Science and Technology (DST), Government of India under the project sanction number EEQ/2016/000631 without any influences in the experimental procedures and results. SD received Maulana Azad National Fellowship, Ministry of Minority Affairs, University Grants Commission (UGC), and Government of India for her Ph.D. work.

\section{Availability of data and materials}

The datasets used and/or analysed during the current study are available from the corresponding author on reasonable request.

\section{Declarations}

\section{Ethics approval consent to participate}

No animal or human volunteers were used in this study.

\section{Consent for publication}

Not applicable.

\section{Competing interests}

The authors declare that they have no competing interests.

\section{Author details}

'Department of Agricultural Biotechnology, Assam Agricultural University, Jorhat, Assam 785013, India. ${ }^{2}$ DBT-North East Centre for Agricultural Biotechnology, Assam Agricultural University, Jorhat, Assam 785013, India. ${ }^{3}$ Department of Plant Pathology, Assam Agricultural University, Jorhat, Assam 785013, India.

Received: 13 January 2021 Accepted: 18 October 2021

Published online: 09 November 2021

\section{References}

Al Khatib M, Harir M, Costa J et al (2018) Spectroscopic characterization of natural melanin from a Streptomyces cyaneofuscatus strain and comparison with melanin enzymatically synthesized by tyrosinase and laccase. Molecules 23(8):1916-1928. https://doi.org/10.3390/molecules23081916 Almeida-Paes R, Almeida-Silva F, Pinto GCM et al (2018) L-tyrosine induces the production of a pyomelanin-like pigment by the parasitic yeast-form of Histoplasma capsulatum. Med Mycol 56(4):506-509. https://doi.org/10. 1093/mmy/myx068

Arun G, Eyini M, Gunasekaran P (2015) Characterization and biological activities of extracellular melanin produced by Schizophyllum commune (Fries). Indian J Exp Biol 53(6):380-387

Baldrian P (2004) Increase of laccase activity during interspecific interactions of white-rot fungi. FEMS Microbiol Ecol 50(3):245-253. https://doi.org/10. 1016/j.femsec.2004.07.005

Bertrand S, Bohni N, Schnee S et al (2014) Metabolite induction via microorganism co-culture: a potential way to enhance chemical diversity for drug discovery. Biotechnol Adv 32(6):1180-1204. https://doi.org/10. 1016/j.biotechadv.2014.03.001

Blagoeva PM (1984) Aminoacids-precursors of melanin synthesis in hamster melanoma. J Cancer Res Clin Oncol 108(3):366-368. https://doi.org/10. 1007/BF00390476

Boddy L (2000) Interspecific combative interactions between wood-decaying basidiomycetes. FEMS Microbiol Ecol 31(3):185-194. https://doi.org/10. 1111/j.1574-6941.2000.tb00683.x

Boddy L, Hiscox J (2016) Fungal ecology: principles and mechanisms of colonization and competition by saprotrophic fungi. Microbiol Spectr 4(6):1-39. https://doi.org/10.1128/microbiolspec.FUNK-0019-2016

Bodke PM, Senthilarasu G, Raghukumar S (2012) Screening diverse fungi for laccases of varying properties. Indian J Microbiol 52(2):247-250. https:// doi.org/10.1007/s12088-011-0204-4

Chatterjee S, Kuang Y, Splivallo R et al (2016) Interactions among filamentous fungi Aspergillus niger, Fusarium verticillioides and Clonostachys rosea: fungal biomass, diversity of secreted metabolites and fumonisin production. BMC Microbiol 16(83):1-13. https://doi.org/10.1186/s12866-016-0698-3

Chi Y, Hatakka A, Maijala P (2007) Can co-culturing of two white-rot fungi increase lignin degradation and the production of lignin-degrading enzymes? Int Biodeterior Biodegrad 59(1):32-39. https://doi.org/10. 1016/j.ibiod.2006.06.025

Debona D, Rodrigues FA, Rios JA et al (2014) The effect of silicon on antioxidant metabolism of wheat leaves infected by Pyricularia oryzae. Plant Pathol 63(3):581-589. https://doi.org/10.1111/ppa.12119

Dullah S, Hazarika DJ, Parveen A et al (2021) Fungal interactions induce changes in hyphal morphology and enzyme production. Mycology 00:1-17. https://doi.org/10.1080/21501203.2021.1932627

Evans JA, Eyre CA, Rogers HJ et al (2008) Changes in volatile production during interspecific interactions between four wood rotting fungi growing in artificial media. Fungal Ecol 1(2-3):57-68. https://doi.org/10.1016/j. funeco.2008.06.001

Eyre C, Muftah W, Hiscox J et al (2010) Microarray analysis of differential gene expression elicited in Trametes versicolor during interspecific mycelial interactions. Fungal Biol 114(8):646-660. https://doi.org/10.1016/j.funbio. 2010.05.006

Gregorio APF, Da Silva IR, Sedarati MR, Hedger JN (2006) Changes in production of lignin degrading enzymes during interactions between mycelia of the tropical decomposer basidiomycetes Marasmiellus troyanus and Marasmius pallescens. Mycol Res 110(2):161-168. https://doi.org/10. 1016/j.mycres.2005.10.002 
Hiscox J, Baldrian P, Rogers HJ, Boddy L (2010) Changes in oxidative enzyme activity during interspecific mycelial interactions involving the white-ro fungus Trametes versicolor. Fungal Genet Biol 47(6):562-571. https://doi. org/10.1016/j.fgb.2010.03.007

Kathuria M, Bhattacharjee A, Sashidhara KV et al (2014) Induction of mitochondrial dysfunction and oxidative stress in Leishmania donovani by orally active clerodane diterpene. Antimicrob Agents Chemother 58(10):59165928. https://doi.org/10.1128/AAC.02459-14

Kuhar F, Castiglia V, Levin L (2015) Enhancement of laccase production and malachite green decolorization by co-culturing Ganoderma lucidum and Trametes versicolor in solid-state fermentation. Int Biodeterior Biodegrad 104:238-243. https://doi.org/10.1016/j.ibiod.2015.06.017

Kurian NK, Bhat SG (2017) Protoprotection and anti-inflammatory properties of non-cytotoxic melanin from marine isolate Providencia rettgeri strain BTKKS1. Biosci Biotechnol Res Asia 14(4):1475-1484. https://doi.org/10. 13005/bbra/2594

Livak KJ, Schmittgen TD (2001) Analysis of relative gene expression data using real-time quantitative PCR and the $2^{-\triangle \Delta C T}$ method. Methods 25(4):402408. https://doi.org/10.1006/meth.2001.1262

Luo F, Zhong Z, Liu L et al (2017) Metabolomic differential analysis of interspecific interactions among white rot fungi Trametes versicolor, Dichomitus squalens and Pleurotus ostreatus. Sci Rep 7(5265):1-11. https://doi.org/10. 1038/s41598-017-05669-3

Medina E, Oliveira A, Medina H, Rangel D (2020) Serendipity in the wrestle between Trichoderma and Metarhizium. Fungal Biol 124(5):418-426. https://doi.org/10.1016/j.funbio.2020.01.002

Peiris D, Dunn WB, Brown M et al (2008) Metabolite profiles of interacting mycelial fronts differ for pairings of the wood decay basidiomycete fungus, Stereum hirsutum with its competitors Coprinus micaceus and Coprinus disseminatus. Metabolomics 4(1):52-62. https://doi.org/10.1007/ s11306-007-0100-4

Rodriguez Estrada AE, Hegeman A, Corby Kistler H, May G (2011) In vitro interactions between Fusarium verticillioides and Ustilago maydis through real-time PCR and metabolic profiling. Fungal Genet Biol 48:874-885. https://doi.org/10.1016/j.fgb.2011.06.006

Rzepka Z, Buszman E, Beberok A, Wrześniok D (2016) Od tyrozyny do melaniny: Ścieżki sygnalizacyjne i czynniki regulujace melanogenezȩ. Postepy Hig Med Dosw 70:695-708

Silar P (2005) Peroxide accumulation and cell death in filamentous fungi induced by contact with a contestant. Mycol Res 109(2):137-149. https:// doi.org/10.1017/S0953756204002230
Slominski A, Zmijewski M, Pawelek J (2012) L-tyrosine and I-DOPA as hormonelike regulators of melanocytes functions. Pigment Cell Melanoma Res 25(1):14-27. https://doi.org/10.1111/J.1755-148X.2011.00898.X

Song Z, Vail A, Sadowsky MJ, Schilling JS (2012) Competition between two wood-degrading fungi with distinct influences on residues. FEMS Microbiol Ecol 79(1):109-117. https://doi.org/10.1111/j.1574-6941.2011.01201.x

Sun S, Zhang X, Sun S et al (2016) Production of natural melanin by Auricularia auricula and study on its molecular structure. Food Chem 190:801-807. https://doi.org/10.1016/j.foodchem.2015.06.042

Sun X, Wu B, Zhou L et al (2017) Isolation and characterization of melanin pigment from yesso scallop Patinopecten yessoensis. J Ocean Univ China 16(2):279-284. https://doi.org/10.1007/S11802-017-3162-6

Tamayo D, Muñoz JF, Lopez Á et al (2016) Identification and analysis of the role of superoxide dismutases isoforms in the pathogenesis of Paracoccidioides spp. PLoS Negl Trop Dis 10(3):e0004481. https://doi.org/10.1371/ journal.pntd.0004481

Toledo AV, Franco MEE, Yanil Lopez SM et al (2017) Melanins in fungi: types, localization and putative biological roles. Physiol Mol Plant Pathol 99:2-6. https://doi.org/10.1016/j.pmpp.2017.04.004

Vantamuri AB, Kaliwal BB (2016) Purification and characterization of laccase from Marasmius species BBKAV79 and effective decolorization of selected textile dyes. 3 Biotech 6(2):1-10. https://doi.org/10.1007/ s13205-016-0504-9

Wei D, Houtman CJ, Kapich AN et al (2010) Laccase and its role in production of extracellular reactive oxygen species during wood decay by the brown rot basidiomycete Postia placenta. Appl Environ Microbiol 76(7):20912097. https://doi.org/10.1128/AEM.02929-09

Zheng W, Zhao Y, Zheng X et al (2011) Production of antioxidant and antitumor metabolites by submerged cultures of Inonotus obliquus cocultured with Phellinus punctatus. Appl Microbiol Biotechnol 89(1):157-167. https://doi.org/10.1007/s00253-010-2846-2

Zhong Z, Li N, He B et al (2019) Transcriptome analysis of differential gene expression in Dichomitus squalens during interspecific mycelial interactions and the potential link with laccase induction. J Microbiol 57(2):127-137. https://doi.org/10.1007/s12275-019-8398-y

\section{Publisher's Note}

Springer Nature remains neutral with regard to jurisdictional claims in published maps and institutional affiliations.
Ready to submit your research? Choose BMC and benefit from:

- fast, convenient online submission

- thorough peer review by experienced researchers in your field

- rapid publication on acceptance

- support for research data, including large and complex data types

- gold Open Access which fosters wider collaboration and increased citations

- maximum visibility for your research: over 100M website views per year

At BMC, research is always in progress.

Learn more biomedcentral.com/submissions 